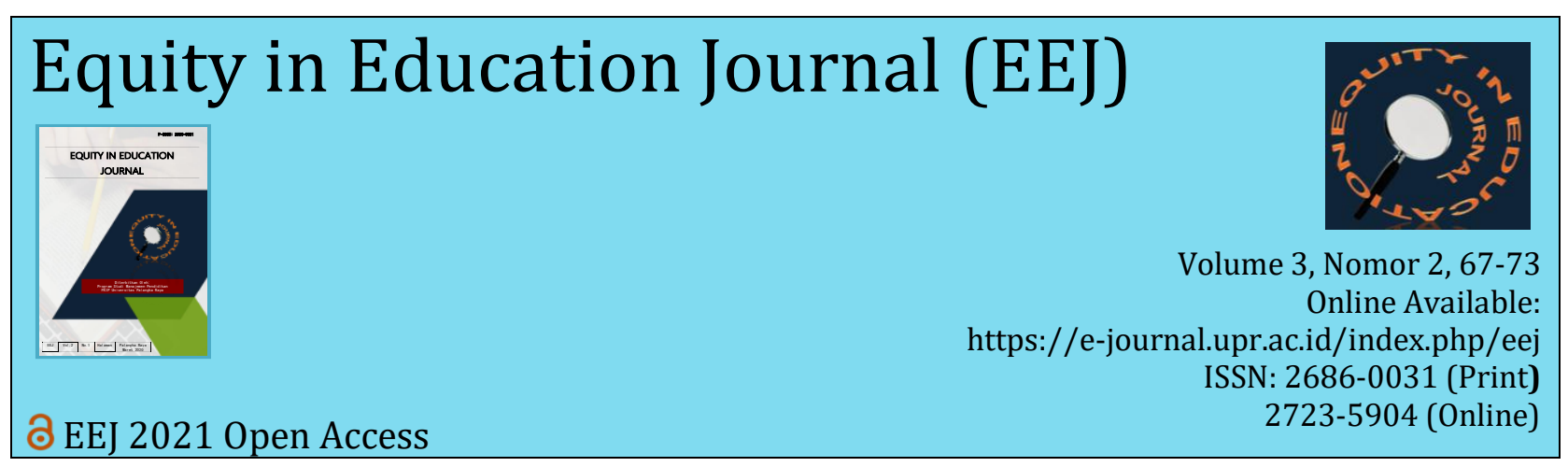

\title{
MANAJEMEN PEMBELAJARAN DALAM JARINGAN (DARING) PADA MASA COVID-19 DI SMAN 2 PALANGKA RAYA
}

\author{
Rika Sagita*, Dagai L. Limin, Sumarnie \\ FKIP, Universitas Palangka Raya, Palangka Raya
}

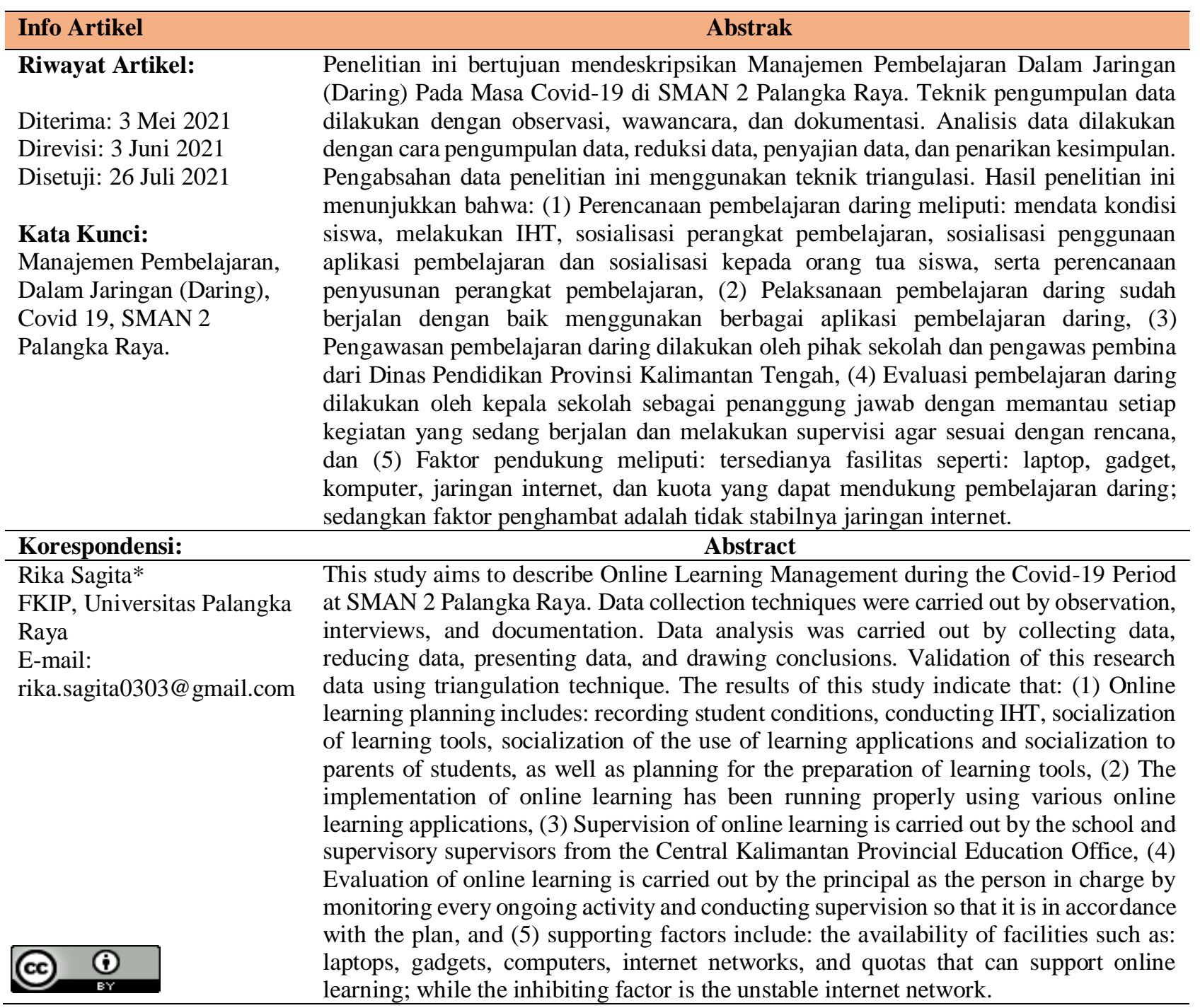

\section{PENDAHULUAN}

Awal tahun 2020, dunia dikejutkan dengan wabah virus corona (Covid-19) yang dikemudian hari menginfeksi hampir seluruh negara di dunia. Pandemi Covid-19 merupakan musibah yang memilukan seluruh penduduk bumi. Seluruh segmen kehidupan manusia di bumi terganggu, tanpa 
kecuali termasuk dunia pendidikan. Banyak negara memutuskan menutup sekolah, perguruan tinggi maupun universitas, termasuk Indonesia. Pemerintah Indonesia harus mengambil keputusan menutup sekolah untuk mengurangi aktivitas yang melibatkan banyak orang, karena pandemi Covid-19 intaraksi secara langsung dihentikan (social distancing) dan diganti dengan sistem pembelajaran daring dan memanfaatkan media internet. Sistem pembelajaran daring merupakan sistem pembelajaran tanpa tatap muka secara langsung antara guru dan siswa tetapi dilakukan dengan mengguakan aplikasi online yang memanfaatkan jaringan internet. Hal ini sesuai dengan Peraturan Menteri Pendidikan dan Kebudayaan Republik Indonesia Nomor 4 Tahun 2020 tentang Pelaksanaan Kebijakan Pendidikan dalam Masa Darurat Penyebaran Covid-19.

Pembelajaran daring merupakan pembelajaran yang menggunakan jaringan internet dengan aksesibilitas, konektivitas, fleksibilitas, dan kemampuan untuk memunculkan berbagai jenis interaksi pembelajaran. Penelitian yang dilakukan oleh Zhang et al (2004) menunjukkan bahwa penggunaan internet dan teknologi multimedia mampu merombak cara penyampaian pengetahuan dan dapat menjadi alternatif pembelajaran yang dilaksanakan dalam kelas tradisional. Pembelajaran daring adalah pembelajaran yang mampu mempertemukan mahasiswa dan dosen untuk melaksanakan interaksi pembelajaran dengan bantuan internet (Kuntarto, 2017). Pada tataran pelaksanaanya pembelajaran daring memerlukan dukungan perangkat-perangkat mobile seperti smartphone atau telepon adroid, laptop, komputer, tablet, dan Iphone yang dapat dipergunakan untuk mengakses informasi kapan saja dan dimana saja (Gikas \& Grant, 2013).

Sistem pembelajaran dilaksanakan melalui perangkat Personal Computer (PC) atau laptop yang terhubung dengan koneksi jaringan internet. Guru dapat melakukan pembelajaran bersama di waktu yang sama menggunakan grup di media sosial seperti: WhatsApp (WA), Google Classroom, Youtube, Facebook, Telegram, Instagram, Zoom Meeting, Google Classroom, Edmodo, dan Schoology (Enriquez, 2014; Sicat, 2015; Iftakhar, 2016; Kumar \& Nanda, 2018). Dengan demikian, guru dapat memastikan siswanya mengikuti pembelajaran dalam waktu yang bersamaan, meskipun di tempat yang berbeda. Penggunaan teknologi mobile mempunyai sumbangan besar dalam lembaga pendidikan, termasuk di dalamnya adalah pencapaian tujuan pembelajaran jarak jauh (Korucu \& Alkan, 2011). Pembelajaran daring menghubungkan peserta didik dengan sumber belajarnya (database, pakar/instruktur, perpustakaan) yang secara fisik terpisah atau bahkan berjauhan namun dapat saling berkomunikasi, berinteraksi atau berkolaborasi (secara langsung/synchronous dan secara tidak langsung/asynchronous). Pembelajaran daring adalah bentuk pembelajaran jarak jauh yang memanfaatkan teknologi telekomunikasi dan informasi, misalnya internet, CD-ROOM (Heinich et al, 2002).

Pada dasarnya pembelajaran harus dilaksanakan secara efektif dan efisien guna memperoleh hasil belajar yang maksimal sesuai dengan apa yang sudah menjadi tujuan pendidikan, adapun untuk mencapai hal tesebut tentunya diperlukan manajemen yang optimal dalam implementasinya. Stoner (dalam Safroni, 2012) menyatakan bahwa manajemen adalah proses perencanaan, pengorganisasian, pemberi pimpinan, dan pengendalian suatu usaha dari suatu organisasi yang penggunaan sumber-sumber daya organisatorisnya ditujukan untuk mencapai tujuan organisasi yang telah ditetapkan. Sumber-sumber daya dimaksud meliputi berbagai sumber daya organisasi (man, materials, machine, dan lain sebagainya) dalam upaya mencapai sasaran organisasi. Pencapaian sasaran terjadi melalui penggunaan manusia (man), bahan produksi (materials) dan mesin (machines) (Weinata, 2001).

SMAN 2 Palangka Raya merupakan salah satu sekolah yang cukup efektif menerapkan metode pembelajaran daring selama masa Covid-19 berlangsung. Hal tersebut dilakukan sekolah untuk menggantikan metode pembelajaran secara tatap muka/langsung untuk membatasi kegiatan sosial berskala besar (social distancing) yang dapat menularkan virus Covid-19 yang akan mengancam kesehatan warga sekolah. Meskipun pembelajaran dilaksanakan secara daring hal ini tidak menurunkan kualitas hasil pembelajaran siswa. Berdasarkan data yang diperoleh dari sekolah diketahui bahwa selama pembelajaran daring berlangsung 70\% siswa telah mencapai hasil belajar yang tinggi, walaupun masih terdapat sebanyak 30\% siswa yang hasil belajarnya belum 
optimal yang lebih disebabkan oleh faktor-faktor seperti: tidak stabilnya jaringan internet dan kurangnya kualitas jaringan internet terutama bagi siswa yang berada di luar kota Palangka Raya, banyaknya tugas yang diberikan sehingga membuat siswa merasa tertekan, siswa merasa bosan dalam mengikuti pembelajaran daring, terdapat siswa yang tidak mengikuti pembelajaran daring, keterbatasan siswa dalam membeli kuota dan terdapat siswa yang memiliki kekurangan fasilitas perangkat elektronik seperti android dan laptop untuk mendukung pembelajaran daring. Untuk mengatasi hal tersebut pihak sekolah melakukan berbagai upaya antara lain dengan mengadakan program remedial dengan meminta siswa yang berada di luar kota Palangka Raya terutama pada daerah yang sulit jangkauan internet untuk kembali ke kota Palangka Raya agar kegiatan pembelajaran tidak terhambat, memberikan bantuan kepada siswa berupa kuota internet terutama bagi siswa yang kurang mampu, dan pihak sekolah menyediakan fasilitas berupa ruang laboratorium komputer yang dapat digunakan guru maupun siswa dalam pembelajaran daring.

Penelitian ini bertujuan untuk mendeskripsikan Manajemen Pembelajaran Dalam Jaringan (Daring) di SMAN 2 Palangka Raya sebagai salah satu sekolah menengah atas negeri di Kota Palangka Raya yang cukup berhasil dalam menerapkan pembelajaran daring pada masa pandemi Covid 19.

\section{METODE}

Penelitian ini menggunakan pendekatan kualitatif dengan metode deskriptif. Sugiyono (2010) menyatakan penelitian deskriptif adalah penelitian yang menganalisis data dengan cara mendeskripsikan atau menggambarkan data yang terkumpul sebagaimana adanya tanpa membuat kesimpulan atau generalisasi. Hadi \& Haryono (2005) menyatakan dalam kajiannya ditekankan pada kebutuhan kualitas penelitian di lapangan, sementara yang lebih dipentingkan adalah ketajaman analisis isi dari pada frekuensi atau bilangan yang diberikan kepada analisisnya. Dari berbagai pengertian mengenai penelitian deskriptif dapat dinyatakan bahwa penelitian deskriptif adalah penelitian yang bermaksud untuk menggambarkan dan mendeskripsikan fenomenafenomena melalui data yang terkumpul dan tentang apa yang dialami oleh subjek peneliti. Sumber data dalam penelitian ini adalah: Wakil Kepala Sekolah bidang Kurikulum, 2 orang Guru, dan 2 Siswa SMAN 2 Palangka Raya.

Teknik pengumpulan data dalam penelitian ini menggunakan observasi, wawancara, dan studi dokumentasi. Analisis data dilakukan melalui tahapan: (1) Pengumpulan Data, (2) Reduksi Data, (3) Penyajian Data, dan (4) Penarikan Kesimpulan, untuk mencari dan menyusun secara sistematis data yang diperoleh dari hasil wawancara, catatan lapangan, dan dokumentasi dengan cara mengorganisasikan data ke kategori, menjabarkan ke dalam unit-unit, melakukan sintesa, menyusun kedalam pola, memilih yang penting dan akan dipeajari, dan membuat kesimpulan sehingga mudah dipahami oleh diri sendiri dan orang lain (Sugiyono, 2011). Pengabsahan Data dalam penelitian ini menggunakan teknik triangulasi sebagaimana dijelaskan Moleong (2012) bahwa untuk menetapkan keabsahan data diperlukan teknik pemeriksaan, salah satunya adalah melalui triangulasi sebagai teknik pemeriksaan keabsahan data yang memanfaatkan sesuatu yang lain. Dalam penelitian ini teknik triangulasi digunakan untuk membandingkan data hasil observasi, wawancara serta dokumentasi.

\section{HASIL DAN PEMBAHASAN}

\section{Perencanaan Pembelajaran Daring}

Berdasarkan hasil temuan penelitian diketahui bahwa perencanaan pembelajaran daring di SMAN 2 Palangka Raya dilakukan dengan mendata kondisi siswa, melakukan In House Training (IHT) kepada guru, melakukan sosialisasi tentang proses pembelajaran, melakukan sosialisasi tentang penyusunan perangkat pembelajaran daring, melakukan sosialisasi tentang penggunaan aplikasi pembelajaran dan melakukan sosialisasi kepada orang tua siswa. Adapun perencanaan yang dilakukan oleh guru meliputi: pembuatan perangkat pembelajaran, menyiapkan aplikasi online dan menyiapkan media dan metode pembelajaran daring. Temuan penelitian terkait 
perencanaan pembelajaran daring ini sejalan dengan pendapat Sudjana (2004) bahwa perencanaan pembelajaran merupakan kegiatan memproyeksikan tindakan apa yang akan dilaksanakan dalam suatu pembelajaran (PBM), yaitu dengan mengkoordinasikan (mengatur dan merespon) komponen-komponen pembelajaran, sehingga arah kegiatan (tujuan), isi kegiatan (materi), cara penyampaian kegiatan (metoda dan teknik), serta bagaimana mengukurnya (evaluasi) menjadi jelas dan sisitematis. Perencanaan pembelajaran dapat dikatakan sebagai pedoman mengajar bagi guru dan pedoman belajar bagi siswa.

\section{Pelaksanaan Pembelajaran Daring}

Berdasarkan hasil temuan penelitian diketahui bahwa dalam pelaksanaan pembelajaran daring dilaksanakan oleh guru dan siswa dengan menggunakan aplikasi yang terhubung pada jaringan internet seperti aplikasi google meet, zoom, skype yang digunakan untuk menyampaikan materi dan melakukan interaksi antara guru dan siswa secara virtual, sedangkan aplikasi whattsapp, kaizala dan google class room digunakan oleh guru dan siswa untuk memberikan tugas dan mengumpulkan tugas. Proses pelaksanaan pembelajaran daring dilakukan dengan menyebarkan kode aplikasi oleh guru kepada siswa sehingga siswa dapat bergabung pada aplikasi pembelajaran yang telah ditentukan oleh guru dan selanjutnya kegiatan pembelajaran dilaksanakan sesuai dengan RPP yang telah guru buat. Temuan penelitian terkait pelaksanaan pembelajaran ini sejalan dengan pendapat Djamarah \& Zain (2010) bahwa pelaksanaan pembelajaran adalah suatu kegiatan yang bernilai edukatif, nilai edukatif mewarnai interaksi yang terjadi antara guru dan siswa. Interaksi yang bernilai edukatif dikarenakan pelaksanaan pembelajaran yang dilakukan diarahkan untuk mencapai tujuan tertentu yang telah dirumuskan sebelum pelaksanaan pembelajaran dimulai. Dalam konteks pelaksanaan pembelajaran daring, Basilaia \& Kvavadze (2020) menyatakan pembelajaran online sebagai pengalaman transfer pengetahuan menggunakan video, audio, gambar, komunikasi teks ke perangkat lunak dan dengan dukungan jaringan internet (Chen, et al., 2020).

\section{Pengawasan Pembelajaran Daring}

Berdasarkan hasil temuan penelitian diketahui bahwa dalam pengawasan pembelajaran daring dilakukan oleh pihak internal, yaitu: Kepala sekolah dan Wakil kepala sekolah bidang Kurikulum, serta pihak ekternal dilakukan oleh Pengawas pembina dari Dinas Pendidikan Provinsi Kalimantan Tengah, yang mana kegiatan pengawasan tersebut dilakukan dengan ikut bergabung (join) pada aplikasi pembelajaran yang digunakan oleh guru pada saat proses pembelajaran untuk melihat dan mengetahui proses kegiatan pembelajaran yang dilaksanakan oleh guru sehingga dapat menilai apabila terdapat hal-hal yang kurang dan perlu diperbaiki agar sesuai dengan perencanaan. Temuan penelitian terkait pengawasan pembelajaran daring ini sejalan dengan pendapat Manullang (2012) bahwa pengawasan merupakan suatu proses untuk menerapkan pekerjaan apa yang sudah dilaksanakan, menilainya dan bila perlu mengoreksi dengan maksud supaya pelaksanaan pekerjaan sesuai dengan rencana semula. Sahertian (2000) menyatakan pengawasan atau supervisi pendidikan adalah usaha memberikan layanan kepada stakeholder pendidikan terutama kepada guru-guru baik secara individu maupun secara kelompok dalam usaha memperbaiki kualitas proses dan hasil pembelajaran.

\section{Evaluasi Pembelajaran Daring}

Berdasarkan hasil temuan penelitian diketahui bahwa dalam evaluasi pembelajaran daring dilakukan oleh kepala sekolah sebagai penanggung jawab yang dilakukan dengan memantau setiap kegiatan yang sedang berjalan dan melakukan supervisi pada setiap bulannya agar dapat mengetahui kegiatan pembelajaran yang dilakukan oleh guru apakah sesuai dengan perencanaan yang telah dibuat sebelumnya. Kepala sekolah melaksanakan evaluasi melalui supervisi dengan melihat secara langsung secara virtual pada saat mengikuti kegiatan pembelajaran yang dilakukan oleh guru melalui aplikasi yang telah ditentukan sebelumnya, melihat catatan hasil laporan baik 
itu jurnal laporan yang dibuat oleh guru dan RPP yang sudah dibuat oleh guru yang mencantumkan hasil tangkap layar kegiatan pembelajaran yang dilakukan oleh kepala sekolah dengan dibantu Wakil Kepala Sekolah bidang Kurikulum untuk ditindaklanjuti ketercapaian dari kegiatan tersebut. Sementara evaluasi yang dilakukan oleh guru terhadap siswa dengan memberikan tugas kepada siswa yang disebarkan lewat aplikasi google classroom, aplikasi kaizala dan aplikasi whattsapp dan tugas diberikan dalam bentuk soal essay, soal uraian dan merangkum materi pembelajaran yang disajikan dalam bentuk PPT dan memberikan pertanyaan-pertanyaan kepada siswa pada saat proses pembelajaran berlangsung yang dilakukan oleh guru untuk melihat seberapa jauh siswa dapat memahami materi yang telah disampaikan sehingga dapat memberikan nilai terhadap tugas yang telah dikerjakan oleh siswa. Temuan penelitian terkait evaluasi pembelajaran daring ini sejalan dengan pendapat Kompri (2015) bahwa evaluasi erat kaitannya dengan penilaian, yaitu memberi nilai atau angka kualitatif terhadap hal yang dievaluasi sehingga tergambar tingkat perbandingan antara hasil yang dicapai dengan patokan yang ditetapkan. Sudjana (2004) menyatakan kegiatan evaluasi berkaitan dengan upaya pengumpulan, pengolahan, analisis, deskripsi dan penyajian data atau informasi sebagai masukan untuk pengambilan keputusan. Kegiatan evaluasi dilaksanakan dengan langkah-langkah untuk mengetahui keterlaksanaan kegiatan program selanjutnya dapat membantu pembuat keputusan dalam mengambil keputusan sehingga dapat menentukan kebijakan program untuk selanjutnya.

\section{Faktor Pendukung dan Penghambat dalam Pembelajaran Daring}

Berdasarkan hasil temuan penelitian diketahui bahwa faktor pendukung dalam pembelajaran daring antara lain meliputi: tersedianya fasilitas seperti gadget, laptop, dan komputer untuk mendukung pembelajaran daring, tersedianya aplikasi online untuk mendukung terlaksananya pembelajaran daring, tersedianya sinyal/jaringan dan kuota untuk mendukung aplikasi online dapat diakses serta tersedianya sumber belajar yang dapat digunakan guru dan siswa dalam pembelajaran daring; sedangkan faktor penghambatnya adalah terkait sinyal/jaringan internet yang dapat mengganggu proses pelaksanaan pembelajaran daring. Mulyasa (2004) menyatakan sarana pendidikan adalah peralatan dan perlengkapan yang secara langsung dipergunakan dan menunjang proses proses pendidikan, khususnya proses belajar mengajar seperti gedung, ruang kelas, meja, kursi, serta alat-alat media pengajaran. Adapun prasarana pendidikan adalah fasilitas yang tidak secara langsung menunjang jalannya proses pendidikan atau pengajaran, seperti halaman, kebun, taman sekolah, dalan menuju sekolah. Dalam pelaksanaan pembelajaran daring yang memanfaatkan aplikasi online diperlukan sarana dan prasarana yang terhubung dengan jaringan internet dan koneksi yang stabil agar proses kegiatan belajar mengajar dapat berlangsung dengan baik; apabila jaringan dan koneksi internet mengalami masalah atau gangguan akan menghambat kegiatan pembelajaran (Sidharta, 1996).

\section{SIMPULAN}

Berdasarkan hasil penelitian dan pembahasan yang telah diuraikan sebelumnya dapat disimpulkan bahwa perencanaan pembelajaran daring di SMA Negeri 2 Palangka Raya dilakukan dengan mendata kondisi siswa, melakukan IHT kepada guru, melakukan sosialisi tentang proses pembelajaran, melakukan sosialisasi tentang perangkat pembelajaran, melakukan sosialisasi tentang penggunaan aplikasi pembelajaran dan melakukan sosialisasi kepada orang tua siswa. Perencanaan yang dilakukan oleh guru dilakukan dengan menyusun perangkat pembelajaran online dan menyiapkan aplikasi online, pelaksanaan pembelajaran daring dilaksanakan oleh guru dan siswa dengan menggunakan aplikasi yang terhubung pada jaringan internet seperti aplikasi google classroom, aplikasi google meet, aplikasi zoom, aplikasi kaizala dan aplikasi whattsapp. Pengawasan pembelajaran dilakukan oleh pihak internal, yaitu: Kepala Sekolah dan Wakil Kepala Sekolah bidang Kurikulum, serta pihak ekternal dilakukan oleh Pengawas pembina dari Dinas Pendidikan Provinsi Kalimantan Tengah. Evaluasi pembelajaran daring dilakukan oleh Kepala Sekolah sebagai penanggung jawab yang dilakukan dengan memantau setiap kegiatan yang 
sedang berjalan dengan melakukan supervisi pada setiap bulannya agar dapat mengetahui kegiatan pembelajaran yang dilakukan oleh guru apakah sesuai dengan perencanaan yang telah dibuat sebelumnya. Evaluasi yang dilakukan oleh guru terhadap siswa, yaitu dengan memberikan tugas kepada siswa yang disebarkan lewat aplikasi google classroom, aplikasi kaizala dan aplikasi whattsapp dan tugas diberikan dalam bentuk soal essay, soal uraian dan merangkum materi pembelajaran yang disajikan dalam bentuk PPT dan memberikan pertanyaan-pertanyaan kepada siswa pada saat proses pembelajaran berlangsung yang dilakukan oleh guru untuk melihat seberapa jauh siswa dapat memahami materi yang telah disampaikan sehingga dapat memberikan nilai terhadap tugas yang telah dikerjakan oleh siswa. Faktor pendukung dalam pembelajaran daring, meliputi: tersedianya fasilitas seperti gadget, laptop, dan komputer untuk mendukung pembelajaran daring, tersedianya aplikasi online untuk mendukung terlaksananya pembelajaran daring, tersedianya sinyal/jaringan dan kuota untuk mendukung aplikasi online dapat diakses serta tersedianya sumber belajar yang dapat digunakan guru dan siswa dalam pembelajaran daring; sedangkan faktor penghambatnya terkait dengan sinyal/jaringan internet yang dapat mengganggu proses pelaksanaan pembelajaran daring.

\section{UCAPAN TERIMAKASIH}

Ucapan terimakasih penulis sampaikan kepada pihak SMAN 2 Palangka Raya yang telah memberikan kesempatan serta dukungan penuh bagi penulis dalam melakukan seluruh proses penelitian, serta redaksi Equity in Education Journal (EEJ) Program Studi Manajemen Pendidikan FKIP Universitas Palangka Raya yang telah memberikan kesempatan artikel kami ini dapat dipublikasikan dalam jurnal ini.

\section{DAFTAR PUSTAKA}

Basilaia, G., \& Kvavadze, D. (2020). Transition to Online Education in Schools during a SARSCoV-2 Coronavirus (COVID-19) Pandemic in Georgia. Pedagogical Research, 5(4). Doi: https://doi.org/10.29333/pr/7937.

Chen, J., Qi, T., Liu, L., Ling, Y., Qian, Z., Li, T., \& Song, Z. (2020). Clinical Progression of Patients with COVID-19 in Shanghai, China. Journal of Infection, 80(5). Doi: 10.1016/j.jinf.2020.03.004.

Djamarah, S. B., \& Zain, A. (2010). Strategi Belajar Mengajar. Jakarta: Rineka Cipta.

Enriquez, M. A. S. (2014). "Students' Perceptions on the Effectiveness of the Use of Edmodo as a Supplementary Tool for Learning." DLSU Research Congress. Doi: https://doi.org/10.1017/CBO9781107415324.004.

Gikas, J., \& Grant, M. M. (2013). Mobile Computing Devices in Higher Education: Student Perspectives on Learning with Cellphones, Smartphones \& Social Media. The Internet and Higher Education, 19. Doi: 10.1016/j.iheduc.2013.06.002.

Hadi, A., \& Haryono. (2005). Metodologi Penelitian Pendidikan. Bandung: CV. Pustaka Setia.

Heinich, R., Molenda, M., Russell, J. D., \& Smaldino, S. E. (2002). Instructional media and Technologies for Learning (7th ed.). New Jersey: Pearson Education.

Iftakhar, S. (2016). Google Classroom: What Works and How?". Journal of Education and Social Sciences, 3(1).

Kompri. (2015). Motivasi Pembelajaran Perspektif Guru dan Siswa. Bandung: PT Remaja Rosdakarya Offset.

Korucu, A. T., \& Alkan, A. (2011). Differences between M-Learning (Mobile Learning) and eLearning, Basic Terminology and Usage of M-Learning in Education. Procedia - Social and Behavioral Sciences, 15. Doi: https://doi.org/10.1016/j.sbspro.2011.04.029.

Kumar, V., \& Nanda, P. (2018). "Social Media in Higher Education". International Journal of Information and Communication Technology Education, 15(1). Doi: https://doi.org/10.4018/ijicte.2019010107. 
Kuntarto, E. (2017). Keefektifan Model Pembelajaran Daring dalam Perkuliahan Bahasa Indonesia di Perguruan Tinggi. Journal Indonesian Language Education and Literature, 3(1). Doi: 10.24235/ileal.v3i1.1820.

Manullang, M. (2012). Manajemen Sumber Daya Manusia. Jakarta: Ghalia Indonesia.

Moleong, L. J. (2012). Metodologi Penelitian Kualitatif. Bandung : PT Remaja Rosdakarya.

Mulyasa, E. (2004). Manajemen Berbasis Sekolah: Konsep, Strategi dan Implementasi. Bandung: PT. Remaja Rosdakarya.

Peraturan Menteri Pendidikan dan Kebudayaan Nomor 4 Tahun 2020 tentang Pelaksanaan Kebijakan Pendidikan dalam Masa Darurat Penyebaran Covid-19.

Safroni. (2012) Manajemen dan Reformasi Pelayanan Publik dalam Konteks Birokrasi Indonesia (Teori, Kebijakan, dan Implementasi). Yogyakarta : Aditya Media Publishing.

Sahertian, P. A. (2000). Konsep Dasar dan Tehnik Supervisi Pendidikan dalam Rangka Mengembangkan Sumber Daya Manusia, Jakarta: PT. Rineka Cipta.

Sicat, A. S. (2015). "Enhancing College Students' Proficiency in Business Writing Via Schoology." International Journal of Education and Research, 3(1).

Sidharta, L. (1996). Internet Informasi Bebas Hambatan. Jakarta: PT. Elex Media Komputindo.

Sudjana, N. (2004). Dasar-dasar Proses Belajar Mengajar. Bandung: Sinar Baru Algensido Offset.

Sugiyono. (2011). Metode Penelitian Kuantitatif Kualitatif dan R\&D. Bandung: Alfabeta.

Weinata, S. (2001). Pendidikan yang Mendidik: Butir-butir Pemikiran Strategis-Reflektif di Seputar Pendidikan. Jakarta : Yudhistira.

Zhang, D., Zhao, J. L., Zhou, L., \& Nunamaker, J. F. (2004). Can e-Learning Replace Classroom Learning? Communications of the ACM, 47(5). Doi: https://doi.org/10.1145/986213.986216. 